\title{
Ascorbate both Activates and Inactivates Bleomycin by Free Radical Generation ${ }^{\dagger}$
}

\author{
Garry R. Buettner ${ }^{\ddagger}$ and Pope L. Moseley ${ }^{*}, \delta$ \\ ESR Center and Pulmonary Division, Department of Internal Medicine, College of Medicine, The University of Iowa, \\ Iowa City, Iowa 52242
}

Received September 23, 1991; Revised Manuscript Received July 24, 1992

\begin{abstract}
The chemotherapeutic agent bleomycin (BLM) is activated by reducing agents to break isolated DNA. Paradoxically, these same reducing agents protect cellular DNA from BLM damage. To resolve this paradox, we have examined the reaction of Fe $\mathrm{F}^{\mathrm{III}} \mathrm{BLM}$ with DNA in the presence of ascorbate. As expected, ascorbate augments $\mathrm{Fe}$ iII $\mathrm{BLM}$-induced DNA damage. However, when ascorbate is added to $\mathrm{Fe}^{\mathrm{III}} \mathrm{BLM}$ prior to exposure to DNA, a redox-inactive BLM is produced in a reaction that generates the ascorbyl radical. This reaction occurs in both ascorbate-supplemented buffer and unsupplemented plasma. In buffered solution, this reaction was found to be stoichiometric; for each mole of BLM present, $6.9 \mathrm{~mol}$ of ascorbate was oxidized and $4.7 \mathrm{~mol}$ of oxygen was consumed. Iron was found to serve only as a catalyst for the reaction. These data suggest that both activation of BLM and the generation of redox-inactive BLM occur via the same reaction and that BLM-induced DNA damage depends upon BLM reaching DNA prior to its interaction with reducing agents.
\end{abstract}

Bleomycin (BLM), ${ }^{1}$ a glycopeptide antibiotic used in the treatment of several different neoplasms, is thought to exert its effects through cellular DNA degradation (Petering et al., 1990; Stubbe \& Kozarich, 1987; Hecht, 1986). The current view is that Fe"IIIBL forms a complex with DNA; in the presence of reducing agents, the $\mathrm{Fe}^{\mathrm{III}} \mathrm{BLM}$ is reduced to $\mathrm{Fe}^{\mathrm{II}}$ BLM which in turn combines with $\mathrm{O}_{2}$ and another reducing equivalent to form an "activated BLM". The activated BLM, $\mathrm{HO}_{2}-\mathrm{Fe}^{\mathrm{III}} \mathrm{BLM}$, is highly oxidizing. It can abstract $\mathrm{H} \cdot$ from DNA (Petering et al., 1990; Stubbe \& Kozarich, 1987; Hecht, 1986), thereby initiating DNA strand scission, generate ${ }^{\circ} \mathrm{OH}$ radicals (Oberley \& Buettner, 1979; Solaiman et al., 1979; Sugiura \& Kikuchi, 1978; Antholine et al., 1991), homolytically cleave hydroperoxides (Padbury et al., 1988), produce thiyl radicals from thiols (Antholine et al., 1991; Antholine \& Petering, 1979), and oxidize HEPES to free radical products (Antholine et al., 1991).

In chemical studies of Fe-BLM and Fe-BLM-DNA, activated BLM is formed from Fe ${ }^{\mathrm{III}} \mathrm{BLM}$ and reducing agents such as thiols (Antholine et al., 1991; Padbury et al., 1988; Antholine \& Petering, 1979; Moseley \& Chalkley, 1987) or ascorbate (Sausville et al., 1978; Natrajan et al., 1990; Aronovitch et al., 1987). Paradoxically, reducing agents have been shown to protect against BLM cytotoxicity in cellular systems (Pohl \& Reidy, 1989). In spite of extensive investigation of BLM chemistry, no model system has been developed to explain this paradox without invoking two separate mechanisms: (1) augmentation of DNA damage by reducing agents and concomitant active-oxygen production; (2) protection by scavenging these oxidants. Moreover, no studies have focused on the actual ascorbate-Fe-BLM chemistry. We report here our observations on this chemistry and propose a unifying model that reconciles the paradox of

† This work was supported by American Cancer Society Grant IN. 122 (G.R.B.) and NIH Grant R29-HL40349 (P.L.M.).

* Address correspondence to this author. Telephone: (319) 356-3745. FAX: (319) 356-7893.

$\ddagger$ ESR Center.

Pulmonary Division, Department of Internal Medicine.

' Abbreviations: A, dehydroascorbic; $\mathrm{AH}^{-}$, ascorbate monoanion; $\mathrm{A}^{--}$, ascorbyl free radical; BLM, bleomycin; HEPES, $N$-(2-hydroxyethyl)piperazine- $N^{\prime}$-2-ethanesulfonic acid. reducing agent-associated bleomycin activation and cell protection.

\section{MATERIALS AND METHODS}

Bleomycin, as Blenoxane, was a gift of Mead Johnson, Evansville, IN, and was used as received. The BLM was dissolved in $18 \mathrm{M} \Omega-\mathrm{cm}$ water; $\mathrm{Fe}(\mathrm{III})$, in $\mathrm{pH} 2 \mathrm{HCl}$, was added to the BLM solution prior to its introduction to buffered reaction solutions. BLM stock solution concentrations were determined using $\epsilon_{291}=17000 \mathrm{M}^{-1} \mathrm{~cm}^{-1}$ (Burger et al., 1985). Adventitious metals were removed from all buffers and verified with ascorbate (Buettner, 1988).

Reacted Fe ${ }^{\mathrm{III}} \mathrm{BLM}$ (redox-inactive BLM) was formed by the incubation of the $\mathrm{Fe}(\mathrm{III})$ and BLM mixture with $100 \mu \mathrm{M}$ ascorbate for $6 \mathrm{~h}$ prior to DNA exposure (no significant differences in results were observed if the incubation time was only $1 \mathrm{~h}$ or $18 \mathrm{~h}$ ). The volume of ascorbate-inactivated FeBLM added to the reaction was adjusted to achieve the final concentrations of $100 \mathrm{nM}$ for BLM and $90 \mathrm{nM}$ for $\mathrm{Fe}(\mathrm{III})$. The reaction was conducted in the presence of $100 \mu \mathrm{M}$ ascorbate, added at the time of reaction with DNA. Ascorbic acid stock solutions were prepared as in reference (Buettner, 1988 ) to minimize air oxidation.

Ascorbate loss was followed by monitoring its absorbance at $265 \mathrm{~nm}$ ( $\epsilon_{265}=14500 \mathrm{M}^{-1} \mathrm{~cm}^{-1}$; Buettner, 1988) using an SLM Aminco 3000 array spectrophotometer. The reaction of ascorbate and BLM appears to be biphasic. To determine the total amount of ascorbate oxidized in the initial, rapid phase of the reaction, tangents were drawn that best represented the initial rapid rate and the later slow rate of ascorbate loss, as shown for the $20 \mu \mathrm{M}$ BLM experiment in Figure 2. The intersection of these tangents was taken as the end point for the initial rapid phase of the reaction. Total ascorbate oxidized in this phase of the reaction was calculated from the change in absorbance from time zero (before introduction of BLM) and the absorbance at the end point. As verification of this approach, similar tangents were drawn after log transformation of the absorbance values. The results of this transformation were consistent with a biphasic reaction, consisting of a relatively fast pseudo-first-order process followed by a second slower pseudo-first-order or a linear 
catalytic process. This transformation produced curves with linear portions for the initial fast phase of the reaction and near-linear portions for the slow phase of the reaction. The slopes in the slow phase were one-fourth to one-tenth those of the fast phase. At longer times, the slopes of the curves would approach zero (see, for example, the $30 \mu \mathrm{M}$ BLM curve of Figure 2). This leveling off of the curve represents the depletion of oxygen. If the solution in the cuvette is periodically reoxygenated, then the slow rate of ascorbate loss continues until the ascorbate is consumed. Thus, we take absorbance at infinity to be zero. The intercepts produced in both approaches were in agreement for the loss of ascorbate in the fast phase of the reaction.

Oxygen uptake studies were done using an YSI Model 53 oxygen monitor. No oxygen uptake was observed in the demetaled ascorbate solutions in the absence of BLM. The amount of oxygen consumed in the initial rapid phase of the reaction was determined using the same techniques described for the determination of ascorbate loss, vide supra.

For supercoiled DNA plasmid preparation, the 5572 base pair plasmid pSVLCAT was placed in Escherichia coli strain HB101, grown in M9 medium supplemented with $5 \mu \mathrm{Ci} / \mathrm{mL}$ $\left[{ }^{3} \mathrm{H}\right]$ thymidine and $100 \mu \mathrm{g} / \mathrm{mL}$ ampicillin, and purified by equilibrium centrifugation in cesium chloride gradients. DNA strand scission was quantitated as previously described (Solomon et al., 1989). Briefly, $12 \mu \mathrm{L}$ containing $1.0 \mu \mathrm{g}$ of radiolabeled DNA (approximately $12000 \mathrm{cpm}$ ) was placed in the bottom of a $400-\mu \mathrm{L}$ Eppendorf tube. To the side of each tube was added $2 \mu \mathrm{L}$ of an Fe ${ }^{\text {III BLM mixture which }}$ contained $0.9 \mu \mathrm{M} \mathrm{Fe}$ (III) mixed with $1.0 \mu \mathrm{M}$ BLM. To the other side of the tube was added $2 \mu \mathrm{L}$ of a $1.0 \mathrm{mM}$ solution of ascorbate. Water $(18 \mathrm{M} \Omega-\mathrm{cm})$ was added to the bottom of the tube so that the final reaction volume was $20 \mu \mathrm{L}$ [final reaction conditions were $1.0 \mu \mathrm{g}$ of DNA, $100 \mathrm{nM}$ BLM, 90 $\mathrm{nM} \mathrm{Fe}(\mathrm{III})$, and $100 \mu \mathrm{M}$ ascorbate]. In tubes that did not contain either BLM, Fe(III), or ascorbate, water alone was added to ensure a constant final volume of $20 \mu \mathrm{L}$. At time zero, all tubes were vortexed to mix the DNA with Fe ${ }^{\text {III BLM }}$ and ascorbate, and the tubes were incubated for $20 \mathrm{~min}$ at room temperature. Following electrophoresis on a $1 \% \mathrm{TAE}$ agarose gel [ $40 \mathrm{mM}$ Tris, $20 \mathrm{mM}$ sodium acetate, and $1 \mathrm{mM}$ metal-free EDTA (Buettner, 1990)], the DNA was stained with $0.5 \mu \mathrm{g} / \mathrm{mL}$ ethidium bromide, and gel slices corresponding to the supercoiled, linear, and nicked forms of plasmid were cut from the gel. Each slice was placed into a glass scintillation vial with $500 \mu \mathrm{L}$ of water $(18 \mathrm{M} \Omega-\mathrm{cm})$ and heated to melt the gel slices. After the vials were cooled, $10 \mathrm{~mL}$ of Scintiverse E (Fischer Scientific) liquid scintillation cocktail was added, and radioactivity was quantitated for each band using a Beckman liquid scintillation counter.

Endogenous plasma ascorbate was analyzed fluorometrically (Brubacher \& Vuilleumier, 1974), except we used ascorbate oxidase to oxidize the ascorbate in the plasma extract prior to condensation with $o$-phenylenediamine. Tocopherol was analyzed fluorometrically (Duggan, 1959), except we added $1.0 \mathrm{mM}$ ascorbic acid to the ethanol/hexane extract of the plasma to prevent tocopherol oxidation.

ESR spectra were collected with a Bruker ESP-300 ESR spectrometer. The ascorbyl radical concentration was determined using 3-carboxyproxyl (Aldrich Chemical Co., Milwaukee, WI) as a standard (Buettner, 1990), taking into account power saturation effects (Buettner \& Kiminyo, 1992).

\section{RESULTS}

To investigate the ability of ascorbate to serve as the "activating" reducing agent in the FeBLM system, we
Table I: Quantitative Assessment of Strand Scission of the 5500 Base Pair ${ }^{3} \mathrm{H}$-Labeled Plasmid pSVLCAT by Fe(III), Fe IIIBLM, and Ascorbate ${ }^{a}$

\begin{tabular}{|c|c|c|c|}
\hline addition & $\begin{array}{l}\text { supercoiled DNA } \\
\text { species (cpm) }\end{array}$ & $\begin{array}{l}\text { \% of DNA cpm } \\
\text { remaining uncut }\end{array}$ & total cpm \\
\hline $\begin{array}{l}\text { none } \\
\text { Fe } \\
\text { FelliILLM-ascorbate } \\
6 \text { h prior to DNA } \\
\text { incubation }\end{array}$ & $\begin{array}{r}10191 \pm 118 \\
4937 \pm 164 \\
10273 \pm 447\end{array}$ & $\begin{array}{l}83 \pm 1.3 \\
50 \pm 2.9 \\
83 \pm 1.6\end{array}$ & $\begin{array}{r}12260 \pm 241 \\
9985 \pm 316 \\
12494 \pm 736\end{array}$ \\
\hline $\begin{array}{l}\mathrm{Fe}^{\mathrm{IIIBLM}} \\
\mathrm{Fe}^{\mathrm{IIL}} \text {-ascorbate }\end{array}$ & $\begin{array}{l}9541 \pm 348 \\
6596 \pm 264\end{array}$ & $\begin{array}{l}77 \pm 1.3 \\
61 \pm 2.9\end{array}$ & $\begin{array}{l}12234 \pm 503 \\
10941 \pm 522\end{array}$ \\
\hline \multicolumn{4}{|c|}{$\begin{array}{l}\text { a Data are expressed as cpm of supercoiled (unnicked) DNA species } \\
\text { nd the percent of total DNA remaining in the unnicked form following } \\
20 \text {-min incubation at room temperature. Decreases in supercoiled species } \\
\text { ccur as DNA strand scission increases. Data represent the mean } \pm \\
\text { EM. }\end{array}$} \\
\hline
\end{tabular}

examined the effectiveness of $\mathrm{Fe}$ (III) and $\mathrm{Fe} \mathrm{e}^{\mathrm{III}} \mathrm{BLM}$ in bringing about DNA strand scission in a supercoiled DNA plasmid (Table I). As previously described (Moseley, 1989), Fe'III. BLM in the absence of a reducing agent is a poor DNA strandbreaking agent (Table I). However, when ascorbate is introduced to the Fe $\mathrm{III}^{\mathrm{III}} \mathrm{BL}-\mathrm{DNA}$ system, the supercoiled DNA is significantly degraded. This degradation exceeds that observed with only $\mathrm{Fe}$ (III) and ascorbate (no BLM). However, if $\mathrm{Fe}^{\mathrm{III}} \mathrm{BLM}$ is exposed to ascorbate prior to its introduction to supercoiled DNA, the DNA sustains substantially less damage; in fact, strand scission is less than with $\mathrm{Fe}$ (III)-ascorbate alone. The time course of this inactivation is rapid. In these studies, partial preservation of unnicked, supercoiled DNA occurs if Fe IIIBLM is incubated with ascorbate for only $20 \mathrm{~min}$ prior to DNA exposure, and reaches a maximum after $40 \mathrm{~min}$ of ascorbate incubation. Introduction of additional iron and/or ascorbate fails to reactivate the ascorbate-inactivated BLM. These results indicate that in the presence of DNA, ascorbate activates Fe IIIBLM, thereby bringing about DNA strand scission, but in the absence of DNA, ascorbate rapidly produces an irreversibly inactive BLM incapable of inducing DNA damage.

Because the reduction of $\mathrm{Fe}^{\mathrm{III}} \mathrm{BLM}$ to the $\mathrm{Fe}$ (II) form is a one-electron process, we reasoned that the introduction of Fe'IIIBLM to a buffered ascorbate solution would result in the formation of the ascorbyl free radical, $\mathrm{A}^{--}$, as a result of the associated one-electron oxidation of ascorbate, $\mathrm{AH}^{-}$:

$$
\mathrm{Fe}^{\mathrm{III}} \mathrm{BLM}+\mathrm{AH}^{-} \rightarrow \mathrm{Fe}^{\mathrm{II}} \mathrm{BLM}+\mathrm{A}^{\cdot-}
$$

As demonstrated by electron spin resonance spectroscopy, the introduction of $\mathrm{Fe}^{\text {III BLM }}$ to a buffered solution of ascorbate results in immediate formation of $\mathrm{A}^{0-}$ (Figure 1). Moreover, when plasma containing $21 \mu \mathrm{M}$ endogenous ascorbate was substituted for the buffered ascorbate solution, Fe IIIBLM-induced formation of $\mathrm{A}^{*-}$ was again readily detected. In both buffered ascorbate solution and plasma, the concentration of $\mathrm{A}^{--}$varied with time; upon introduction of $\mathrm{Fe}^{\mathrm{III}} \mathrm{BLM}$, the $\mathrm{A}^{*-}$ concentration increased sharply, and subsequently decreased to a near-steady-state level. The concentration of the ascorbyl free radical reflects the rate of ascorbate oxidation (Buettner, 1990); the higher the ascorbyl radical concentration, the higher the rate of ascorbate oxidation. This decrease and near-leveling-off of the $\mathrm{A}^{- \text {- }}$ signal suggest that the chemical reactions that generate activated BLM and subsequently redox-inactive BLM have gone to completion and that a stoichiometric relation exists in the BLM-ascorbate reaction regardless of whether it takes place in plasma or buffer.

To examine this stoichiometry in more detail, we monitored the oxidation of ascorbate by following its loss of absorbance 


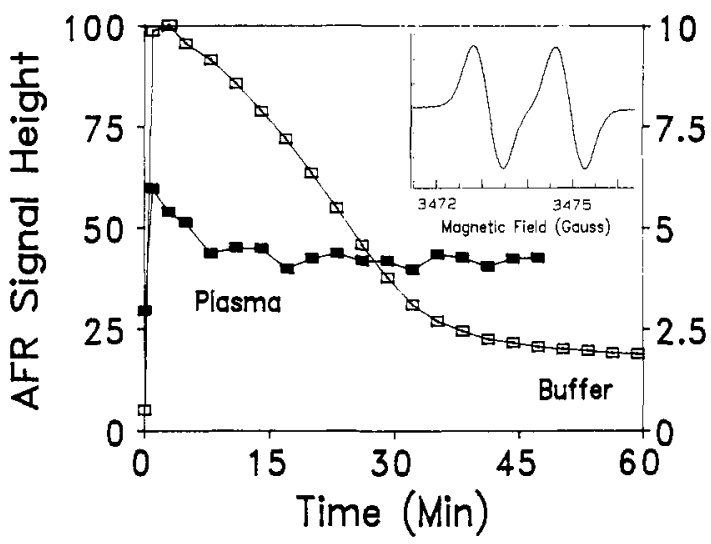

FIGURE 1: ESR signal of the ascorbyl free radical. (Inset) ESR spectrum of the ascorbyl free radical $\left(a^{\mathrm{H}}=1.83 \mathrm{G}\right)$ observed when $30 \mu \mathrm{M}$ BLM that had been incubated with $10 \mu \mathrm{M}$ Fe(III) was introduced to a $500 \mu \mathrm{M}$ ascorbate solution. ( $\square$, Left ordinate scale) The ascorbyl free radical concentration is observed to increase from background levels when $30 \mu \mathrm{M}$ BLM that had been incubated with $10 \mu \mathrm{M} \mathrm{Fe}$ (III) was introduced into a $500 \mu \mathrm{M}$ ascorbate solution in $50 \mathrm{mM} \mathrm{pH} 7.4$ phosphate buffer (typical of three experiments). ( Right ordinate scale) The ascorbyl free radical concentration is also observed to increase when $30 \mu \mathrm{M}$ BLM that had been incubated with $10 \mu \mathrm{M} F$ (III) was introduced into freshly prepared canine plasma (typical of three experiments). The endogenous ascorbate level in this plasma sample was $21 \mu \mathrm{M}$ before introduction of the BLM and iron. The endogenous $\alpha$-tocopherol level was $17 \mu \mathrm{M}$. All ESR spectra were collected using the same instrument settings, except for receiver gain (modulation amplitude, $0.61 \mathrm{G}$; scan, $6 \mathrm{G} / 84 \mathrm{~s}$; time constant, $0.66 \mathrm{~s}$ ). All results were normalized to the percent of the largest signal. The largest ascorbyl radical ESR signal corresponds to a concentration of $225 \mathrm{nM}$. With our experimental conditions, other concentrations of $\mathrm{A}^{--}$are linearly correlated with signal height.

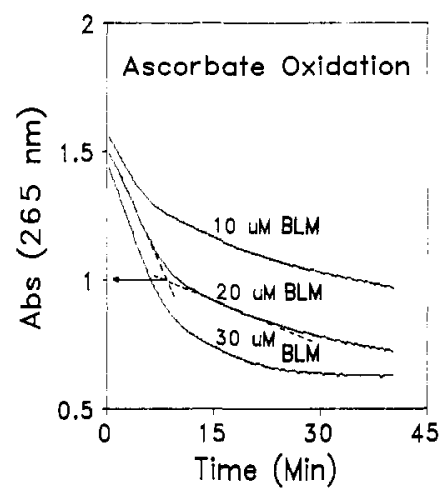

FIGURE 2: Ascorbate loss. These curves show the rate of ascorbate oxidation as monitored by the loss of its $265-\mathrm{nm}$ absorbance after introduction of BLM. BLM at 10,20 , and $30 \mu \mathrm{M}$ was introduced to $\approx 500 \mu \mathrm{M}$ ascorbate solutions, in $50 \mathrm{mM}$ metal-free phosphate buffer, $\mathrm{pH} 7.4$, and monitored in 2-mm path-length quartz cuvettes. The BLM had been incubated with $10 \mu \mathrm{M} F e($ III) prior to its introduction into the ascorbate solution. There was no loss of ascorbate prior to introduction of BLM into these solutions. Minor variations in the initial ascorbate concentration from sample to sample occurred; however, because ascorbate was in excess and it was the change in ascorbate concentration that was important, these variations had no influence on our results. At higher BLM concentrations and at longer times, significant oxygen depletion in the cuvette would occur, causing the slowing of the reaction. See, for example, the $30 \mu \mathrm{M}$ BLM curve at times greater than $\approx 20 \mathrm{~min}$. If the solution is reoxygenated, loss of ascorbate is resumed with rates comparable to the slow process. Repeated reoxygenation over many hours results in the depletion of ascorbate.

at $265 \mathrm{~nm}$ (Figure 2). The initial oxidation of ascorbate following the introduction of $\mathrm{Fe}^{\mathrm{III}} \mathrm{BLM}$ into a buffered ascorbate solution is rapid. This oxidation appears to be biphasic in that there is initially a period of rapid ascorbate loss followed by a much slower rate of loss. The results of log

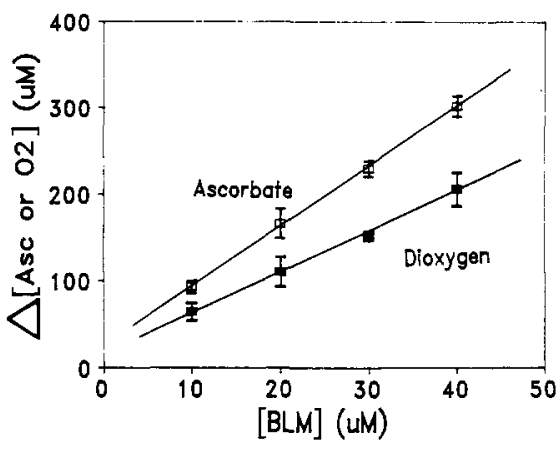

FiguRE 3: Dioxygen and ascorbate (Asc) losses vs [BLM]. These plots demonstrate that the total amounts of ascorbate oxidized and dioxygen consumed in the initial rapid phase of the reaction are stoichiometrically determined by the initial amount of BLM present. $(\square)$ is the change in ascorbate concentration (micromolar) versus BLM concentration (micromolar); slope $=6.9 \pm 0.1 \mathrm{~mol}$ of ascorbate/ mol of BLM. ( $\square$ ) is the change in oxygen concentration (micromolar) versus BLM concentration (micromolar); slope $=4.7 \pm 0.2 \mathrm{~mol}$ of dioxygen $/ \mathrm{mol}$ of BLM. Correlation coefficients are 0.999. Each point represents a minimum of five determinations.

transformation of the absorbance data are consistent with an initial fast pseudo-first-order process followed by a much slower process, approximately 4-10 times slower. We interpret these results to indicate two separate, sequential processes: (1) the initial rapid phase of the reaction we associate with the ascorbate-driven activation of BLM to form "activated-BLM" and its subsequent reaction to form redox-inactive BLM; and (2) the slow phase we interpret to be the metal-catalyzed oxidation of ascorbate by redox-inactive BLM, as is observed for many iron or copper chelates (Buettner, 1986).

In the reaction mixture, oxygen is consumed; periodic reoxygenation results in continued consumption of ascorbate with a rate consistent with the slow phase until all the ascorbate is consumed. In the vocabulary that has developed in this field, "activated-BLM" refers to the highly oxidizing oxygen complex of BLM that is proposed to be the species that initiates DNA strand scission, while "redox-inactive-BLM" is an altered form of BLM that is no longer able to form this highly oxidizing species, and is thus incapable of bringing about DNA strand scission. However, the term redox-inactive should not be interpreted to mean that this form of BLM is not capable of catalyzing the slow oxidation of ascorbate as we observed here. In the presence of excess ascorbate and dioxygen, we found that the total amount of ascorbate oxidized in the rapid phase was directly determined by the initial concentration of BLM. From Figure 3, we see that for each mole of BLM present, $6.9 \pm 0.1 \mathrm{~mol}$ of ascorbate is oxidized.

After the formation of $\mathrm{Fe}^{\mathrm{II}} \mathrm{BLM}$, reaction 1, the subsequent production of activated BLM would most likely proceed as follows:

$$
\begin{aligned}
& \mathrm{Fe}^{\mathrm{II}} \mathrm{BLM}+\mathrm{O}_{2} \rightarrow \mathrm{O}_{2}-\mathrm{Fe}^{\mathrm{II}}{ }^{\mathrm{BLM}} \\
& \mathrm{O}_{2}-\mathrm{Fe}^{\mathrm{II}} \mathrm{BLM}+\mathrm{AH}^{-} \rightarrow \underset{\text { "activated-BLM" }}{\mathrm{O}_{2}{ }^{2-}-\mathrm{Fe}^{\mathrm{III}} \mathrm{BLM}^{\prime}}+\mathrm{A}^{\cdot-} \\
& 2 \mathrm{~A}^{*-}+\mathrm{H}^{+} \rightarrow \mathrm{AH}^{-}+\mathrm{A}
\end{aligned}
$$

In reaction 3 , we show ascorbate providing the second reducing equivalent required to generate activated BLM; however, the ascorbyl radical could also provide this equivalent. Because the ascorbyl radical readily undergoes a dismutation reaction (reaction 4), the observed stoichiometry would not be influenced by this possibility. In addition, it is possible that the second reducing equivalent to form activated BLM could come from another $\mathrm{Fe}^{\mathrm{II}} \mathrm{BLM}$. However, in the presence of a large 
excess of ascorbate, this contribution would probably be minimal; again, the observed stoichiometry would not be changed with this possibility.

Because both a reducing agent and oxygen are required to activate BLM, the reaction of ascorbate and BLM should also result in the consumption of oxygen (reaction 2). Indeed, when ascorbate was introduced into a neutral solution $(\mathrm{pH}$ 7.4) of Fe'IIBLM, oxygen consumption resulted immediately. This loss of oxygen not only parallels the loss of ascorbate but also is similarly biphasic (not shown). In the presence of excess ascorbate, the total amount of oxygen consumed in the initial rapid phase of the reaction is determined by the concentration of BLM. As seen in Figure 3, $4.7 \pm 0.2 \mathrm{~mol}$ of oxygen is consumed for each mole of BLM present.

Looking separately at the role of Fe(III) in the BLMascorbate reaction, we expected that ascorbate would reduce the $\mathrm{Fe}^{\mathrm{III}} \mathrm{BLM}$ to $\mathrm{Fe}^{\mathrm{II} B L M}$ and that there would be a stoichiometric relationship between iron concentration and ascorbate oxidized as well as oxygen consumed. It had previously been reported that the introduction of $\mathrm{Fe}$ (II) into an oxygenated BLM solution inactivates BLM's ability to nick DNA in a stoichiometric fashion; for complete inactivation, $\approx 7 \mathrm{~mol}$ of $\mathrm{Fe}(\mathrm{II})$ is required for each mole of BLM, assuming no other side reactions occur (Nakamura \& Peisach, 1988). However, much to our surprise the stoichiometry of ascorbate oxidation and oxygen consumption in our experiments was not dependent on the concentration of $\mathrm{Fe}$ (III) associated with the BLM but rather only on the initial concentration of BLM. However, at fixed concentrations of BLM, the initial rates of ascorbate oxidation and oxygen consumption are dependent on the concentration of $\mathrm{Fe}$ (III). Thus, for the inactivation of BLM, the iron appears to act only as a catalyst.

\section{DISCUSSION}

In these experiments with BLM and ascorbate, we observed a biphasic oxidation of ascorbate and a biphasic loss of dioxygen. The initial rapid phase of the reaction we attribute to the reactions that produce activated BLM. In the absence of DNA, activated BLM decays to form oxidized BLM, i.e., redox-inactive BLM, which has impaired DNA strand scission activity (Petering et al., 1990). The slow process that we observe at the end of the rapid phase of the reaction we believe is the simple metal-catalyzed oxidation of ascorbate by the redox-inactive Fe-BLM, similar to what is observed for many transition-metal complexes (Buettner, 1986). This slow rate of ascorbate oxidation and oxygen loss together with our observations that the ascorbate-produced, redox-inactive BLM is a poor DNA nicking agent indicates that redox-inactive BLM is a very poor catalyst for all oxidation processes.

The stoichiometry we observe for the rapid phase of the reaction is in line with that observed (Nakamura \& Peisach, 1988) for the inactivation of BLM by Fe(II). They found that 6 equiv of $\mathrm{Fe}$ (II) converted 0.84 equiv of BLM to a redoxinactive form; this corresponds to an ideal 7 reducing equiv/ BLM. However, the extrapolation of the data of Nakamura and Peisach (1988) indicates that in the limit, 14 equiv of $\mathrm{Fe}$ (II) would be required for complete inactivation of 1 equiv of BLM. In our experiment, we started with $\mathrm{Fe}$ (III). Therefore, if the results of Nakamura and Peisach hold, we would also require 14 reducing equiv from ascorbate to bring about formation of redox-inactive BLM: 2 to produce activated BLM and 12 being spent to completely inactivate BLM. However, ascorbate is a two-electron reducing agent; therefore,
$7 \mathrm{~mol}$ of ascorbate would be required. Indeed, our $6.9 \mathrm{~mol}$ of ascorbate oxidized per mole of BLM is in remarkable agreement with the results of Nakamura and Peisach (1988).

Our results regarding oxygen consumption are less clearcut. If all 14 ascorbate-derived reducing equiv consumed during the formation of redox-inactive BLM from Fe $\mathrm{F}^{\mathrm{III}} \mathrm{BLM}$ ended up on $\mathrm{O}_{2}$, forming fully reduced oxygen (equivalent to water), then $14 / 4=3.5 \mathrm{~mol}$ of $\mathrm{O}_{2} / \mathrm{mol}$ of $\mathrm{BLM}$ would have been consumed; we observed $4.7 \mathrm{~mol}$ of $\mathrm{O}_{2} / \mathrm{mol}$ of BLM. The "excess" oxygen consumption suggests that BLM is providing reducing equivalents to oxygen as the inactivation process occurs. This is quite reasonable-one proposed mechanism of DNA strand scission by activated BLM has as the initial step hydrogen atom transfer from a deoxyribose ring to activated BLM. The DNA then reacts with $\mathrm{O}_{2}$, i.e., provides reducing equivalents to $\mathrm{O}_{2}$, and the oxidation process proceeds (Stubbe \& Kozarich, 1987). In a parallel manner, we can reason that some of the reducing equivalents that find their way to oxygen are from ascorbate while the remaining equivalents come from the oxidation of BLM itself. Clearly, some change in BLM must occur to render it redox-inactive; a reasonable hypothesis is that some portion of the BLM molecule is oxidized, thereby rendering it redox-inactive.

The important conclusions that can be drawn from our experiments are as follows: (1) Ascorbate inactivates BLM with respect to its ability to nick DNA; in fact, ascorbateinactivated Fe $\mathrm{e}^{\mathrm{III}} \mathrm{BLM}$ is even less effective in nicking DNA than Fe III-ascorbate with no BLM at all. (2) The reaction of $\mathrm{Fe}^{\mathrm{III}} \mathrm{BLM}$ with ascorbate, which yields redox-inactive BLM, is associated with the generation of the ascorbyl free radical in both ascorbate-supplemented buffer and unsupplemented plasma. (3) The reaction of BLM with ascorbate is stoichiometric with respect to (a) ascorbate oxidation, (b) oxygen consumption, and (c) BLM concentration. (4) Iron serves only as a catalyst rather than as a reactant for ascorbatedriven inactivation of BLM.

BLM's cellular toxicity is thought to result from oxidative strand scission of DNA; FeBLM is considered to be the active agent, being activated by reducing agents (Petering et al., 1990; Stubbe \& Kozarich, 1987; Hecht, 1986). At the same time, because cellular reducing agents such as ascorbate can scavenge free radicals and other oxidative species, it has been traditionally assumed that such reducing agents would protect cells by repairing the oxidative processes initiated by BLM. Thus, the currrently held model of the BLM-reducing agent interaction presents a dichotomy-activation of BLM by reducing agents through the donation of an electron, which generates highly oxidizing species and oxy radicals, versus the scavenging of these same oxidants by these same reducing agents. However, we have clearly demonstrated that in the presence of DNA ascorbate initiates BLM-induced strand scission whereas in the absence of DNA ascorbate reacts with BLM to produce the ascorbyl radical and a redox-inactive BLM incapable of nicking DNA. These results elicit a new and unifying hypothesis to explain how reducing agents can both promote BLM toxicity and yet also protect cells by the same radical-generating mechanism. We propose that reducing agents, such as ascorbate, protect cells from BLM toxicity by rendering $B L M$ redox-inactive prior to DNA binding.

\section{ACKNOWLEDGMENT}

We thank Kitonga Kiminyo and Erik Wallen for their excellent technical assistance and the reviewers for their thought-provoking comments. 


\section{REFERENCES}

Antholine, W. E., \& Petering, D. H. (1979) Biochem. Biophys. Res. Commun. 90, 384-389.

Antholine, W. E., Kalyanaraman, B., Templin, J. A., Byrnes, R. W., \& Petering, D. H. (1991) Free Radical Biol. Med. 10, 119-123.

Aronovitch, J., Godinger, D., Samuni, A., \& Czapski, G. (1987) Free Radical Res. Commun. 2, 241-258.

Brubacher, G., \& Vuilleumier, J. P. (1974) in Clinical Biochemistry, Principles and Methods (Curtius, H. C., \& Roth, M., Eds.) Vol. 2, pp 989-997, de Gruyter, Berlin.

Buettner, G. R. (1986) Free Radical Res. Commun. 1, 349-353.

Buettner, G. R. (1988) J. Biochem. Biophys. Methods 16, 27 40.

Buettner, G. R. (1990) Free Radical Res. Commun. 10, 5-9.

Buettner, G. R., \& Kiminyo, K. P. (1992) J. Biochem. Biophys. Methods 24, 147-151.

Burger, R. M., Horwitz, S. B., \& Peisach, J. (1985) Biochemistry 24, 3623-3629.

Duggan, D. E. (1959) Arch. Biochem. Biophys. 84, 116-122.

Hecht, S. M. (1986) Acc. Chem. Res. 19, 383-391.
Moseley, P. L. (1989) Am. J. Physiol. 257, C882-C887.

Moseley, P. L., \& Chalkley, R. (1987) J. Lab. Clin. Med. 110 , 618-623.

Nakamura, M., \& Peisach, J. (1988) J. Antibiot. 41, 638-647.

Natrajan, A., Hecht, S. M., van der Marel, G. A., \& van Boom, J. H. (1990) J. Am. Chem. Soc. 112, 3997-4002.

Oberley, L. W., \& Buettner, G. R. (1979) FEBS Lett. 97, 47-49.

Padbury, G., Sligar, S. G., Labeque, R., \& Marnett, L. J. (1988) Biochemistry 27, 7846-7852.

Petering, D. H., Byrnes, R., \& Antholine, W. E. (1990) Chem.Biol. Interact. 73, 133-182.

Pohl, H., \& Reidy, J. A. (1989) Mutat. Res. 224, 247-252.

Sausville, E. A., Peisach, J., \& Horwitz, S. B. (1978) Biochemistry $17,2740-2746$.

Solaiman, D., Rao, E. R., Petering, D. H., Sealy, R. C., \& Antholine, W. E. (1979) Int. J. Radiat. Oncol., Biol., Phys. 5, 1519-1521.

Solomon, L. R., Beerelli, R. D., \& Moseley, P. L. (1989) Biochemistry 28, 9932-9937.

Stubbe, J., \& Kozarich, J. W. (1987) Chem. Rev. 87, 11071136.

Sugiura, Y., \& Kikuchi, T. (1978) J. Antibiot. 31, 1310-1312. 